\title{
Effect of Treating Apple Trees with Acibenzolar-S-Methyl on Fire Blight and Expression of Pathogenesis-Related Protein Genes
}

\author{
Kimberly Maxson-Stein, Sheng-Yang He, Raymond Hammerschmidt, and Alan L. Jones, Department of Plant \\ Pathology, Michigan State University, East Lansing 48824-1312
}

\begin{abstract}
Maxson-Stein, K., He, S.-Y., Hammerschmidt, R., and Jones, A. L. 2002. Effect of treating apple trees with acibenzolar- $S$-methyl on fire blight and expression of pathogenesis-related protein genes. Plant Dis. 86:785-790.

Acibenzolar-S-methyl (ASM, Actigard $50 \mathrm{WG),} \mathrm{a} \mathrm{synthetic} \mathrm{inducer} \mathrm{of} \mathrm{systemic} \mathrm{acquired} \mathrm{resis-}$ tance (SAR) and pathogenesis-related (PR) proteins, was evaluated for the control of fire blight on apple trees in the field and for PR protein gene expression in apple seedlings in the greenhouse. Expression of putative genes related to SAR induction was elevated in ASM-treated apple seedlings 2 to 7 days after treatment; levels of PR-1 and PR-8 RNA were increased 10fold and PR-2 RNA was increased 100-fold in ASM-treated seedlings over levels in untreated seedlings. Spurs and shoots on Jonathan trees sprayed with ASM at $75 \mathrm{mg}$ a.i./liter at pink and at weekly intervals thereafter had significantly less fire blight than untreated trees, both from natural infection and following artificial inoculation with the pathogen. Less fire blight was observed on trees sprayed weekly with ASM than on trees sprayed biweekly. The severity of fire blight on inoculated shoots of Fuji apple decreased with increasing rates of ASM (0 to 300 $\mathrm{mg}$ a.i./liter), and ASM combined with streptomycin showed enhanced activity over ASM at 75 $\mathrm{mg}$ a.i./liter alone. In general, ASM was not superior to streptomycin for fire blight control, but integrating a weekly schedule of ASM, preferably at $150 \mathrm{mg}$ a.i./liter, with a schedule of streptomycin designed for blossom blight control appears promising for overall improvement in fire blight control.
\end{abstract}

Fire blight, caused by Erwinia amylovora, is a devastating disease of apple (Malus $\times$ domestica Borkh.); it destroys the bearing tissues and frequently results in tree death. Losses from fire blight in Michigan in 2000 were estimated at more than $\$ 42$ million: losses so severe they will reshape the way apples are grown in Michigan for years to come (16). The best strategy for controlling fire blight is to prevent infection during the bloom period before wind-driven rain and pollinating insects spread the disease throughout the orchard. Chemical control measures include copper compounds sprayed at bud break followed by two to four applications of an antibiotic during the bloom period. There are disadvantages to the use of these bactericides. Copper ions are sometimes toxic and can adversely affect fruit finish; limiting the use of copper to bud break avoids the fruit injury problem (27). Streptomycin can be highly effective for fire blight control; however, it is not registered on apple in all countries, and in some areas, including Michigan, the bacteria have developed resistance to streptomycin $(3,4,24,25)$. Apple growers need new

Corresponding author: A. L. Jones

E-mail: jonesa@msu.edu

Accepted for publication 2 March 2002.

Publication no. D-2002-0506-01R

(C) 2002 The American Phytopathological Society chemicals with increased efficacy to prevent the severe losses currently suffered from fire blight.

The lack of bactericides and of highly disease resistant cultivars is driving efforts to develop alternative control measures. Novel approaches to fire blight control include the use of chemicals that stimulate the tree's natural defense mechanisms through a plant resistance phenomenon called "systemic acquired resistance" (SAR). Induction of SAR is often associated with an increase in accumulation of salicylic acid (SA) and increased expression of several pathogenesis-related protein genes (PR genes) $(13,28)$. The SAR defense response can also be triggered in plants by exogenous applications of SA and other elicitor compounds (31). One of the activators of SAR is acibenzolar- $S$ methyl (ASM), which is marketed as Actigard and Bion (Syngenta Crop Protection, Inc., Greensboro, NC). ASM has demonstrated efficacy in preventing or reducing diseases of plants caused by a variety of bacterial, fungal, and viral pathogens $(8,9,14,15,30)$. In recent field trials, ASM has been shown to increase resistance in bell pepper (22) and tomato (17) to bacterial infections, in flue-cured tobacco to viral infection (5), and in melons to fungal infections (10). Recently, Ishii et al. (11) reported that ASM increased the resistance of Japanese pear to rust (Gymnosporangium asiaticum) and scab (Venturia nashicola). Spray treatments of ASM have exhibited some activity against fire blight, but further work is needed to develop this approach into a treatment strategy for controlling fire blight on apple trees (2). The objective of this study was to identify selected PR genes in apple, determine if sprays of ASM increase the expression of these genes specifically, and evaluate the influence of application rate and interval on the level of fire blight incidence and severity.

\section{MATERIALS AND METHODS}

Polymerase chain reaction $(\mathrm{PCR})$ of target genes from apple. Amino acid sequences for PR-proteins and actin found in GenBank were aligned with the aid of DNASTAR's Lasergene software (DNASTAR Inc., Madison, WI) to reveal conserved regions suitable for designing PCR primers that would detect the corresponding genes in apple DNA. The sequences for PR-1 were Nicotiana tabacum, GenBank accession number AAF76440; Zea mays, AAC25629; Capsicum annuum, AAC06244; and Vitis vinifera, CAA05868; for PR-2 were $N$. tabacum, AAA34103; Z. mays, AAA74320; and Prunus persica AAA92013; for PR-8 were Cucumis sativus, AAC37394; Vitis vinifera, P51614; and Hevea brasiliensis, P23472; and for actin were Homo sapiens, NP_001605; Neurospora crassa, P78711; and Phytophthora infestans, JE0414. Degenerate primer pairs aj263-aj264, aj277-aj278A, aj281A-aj282A, and aj665-aj666 were designed for the amplification of PR-1, PR-2, PR-8, and actin gene fragments, respectively (Table 1 ).

DNA was isolated from $0.1 \mathrm{~g}$ fresh weight of mature Gala and McIntosh apple leaves from the field with a DNeasy Plant Minikit according to the manufacturer's instructions (Quiagen Inc., Valencia, CA). Degenerate primer pairs were used to amplify DNA fragments of PR-1, PR-2, PR-8 and actin from Gala DNA. Reactions were performed in a PTC-100 Programmable Thermal Cycler (MJ Research, Inc., Watertown, MA). PCR mixtures $(50 \mu \mathrm{l})$ for PR gene amplification consisted of $1 \times$ PCR Buffer (10 mM Tris-HCl, pH 8.3), $1.5 \mathrm{mM}$ $\mathrm{MgCl}_{2}, 160 \mu \mathrm{M}$ dNTPs, $25 \mathrm{pM}$ of each primer in pairs aj263-aj264, aj277-aj278A, or aj281A-282A, $1.25 \mathrm{U}$ of Taq DNA polymerase (Life Technologies, Gaithersburg, MD), and 0.015 to $0.120 \mathrm{pM}$ of apple DNA. Reaction mixtures were covered with $40 \mu$ lof mineral oil prior to amplification. Cycling parameters were $94^{\circ} \mathrm{C}$ for 5 min followed by 30 cycles of $94^{\circ} \mathrm{C}$ for 1 
min; $47^{\circ} \mathrm{C}$ (PR-1 and PR-8) or $53^{\circ} \mathrm{C}$ (PR2) for $2 \mathrm{~min}$; and $72^{\circ} \mathrm{C}$ for $1 \mathrm{~min}$. PCR mixtures $(50 \mu \mathrm{l})$ for the amplification of the actin gene consisted of $1 \times$ Expand Long Template PCR System Buffer (Roche Molecular Biochemicals, Indianapolis, IN), $10 \mathrm{mM}$ dNTPs, $40 \mathrm{pM}$ of each primer, 2.5 U Taq DNA polymerase (Life Technologies), and 0.015 to $0.120 \mathrm{pM}$ of apple DNA. Cycling parameters were $94^{\circ} \mathrm{C}$ for 2 min followed by 30 cycles of $94^{\circ} \mathrm{C}$ for 30 $\mathrm{s}$; $50^{\circ} \mathrm{C}$ for $1 \mathrm{~min}$; and $72^{\circ} \mathrm{C}$ for $1 \mathrm{~min}$. PCR products $(8 \mu \mathrm{l})$ were separated on a $2 \%$ agarose gel, run in $0.5 \times$ Tris-borateEDTA (TBE) buffer, stained with ethidium bromide, and visualized with UV light. The amplified fragments were purified with Wizard PCR Preps DNA Purification System (Promega Corp., Madison, WI) and sequenced at the Michigan State University Department of Energy Plant Research Laboratory sequencing facility using $\mathrm{ABI}$ dye-terminator chemistry (Applied Biosystems, Foster City, CA).

To determine if the PR and actin genes were expressed in ASM-treated apple tissue, total RNA was isolated from leaves harvested 3 days after 28-year-old Jonathan trees were sprayed with ASM at $75 \mathrm{mg}$ a.i./liter. Stratagene (La Jolla, CA) constructed an apple ZAP Express Custom cDNA library from the isolated RNA. Degenerate primers (Table 1) were then used to amplify fragments of PR-1, PR-2, PR-8, and actin from the cDNA library.

An apple genomic DNA library was used as a template to amplify longer regions of each PR gene. To construct the library, McIntosh genomic DNA was di- gested with restriction enzyme $S c a$ I. Complementary adapter oligonucleotides (5'CTA ATA CGA CTC ACT ATA GGG CTC GAG CGG CCG CCC GGG CAG GT-3' and 5'-P-AC CTG CCC- $\mathrm{NH}_{2}-3^{\prime}$ ) were ligated onto the ends of the digested DNA according to the method of Siebert et al. (26). The $5^{\prime}$ end of the apple PR-1 gene was amplified from the adapter-ligated library using nested PCR. Primers AP1 and AP2 (Table 1), which were complementary to regions in the long adapter oligonucleotide shown above, were paired with aj629 and then with aj630. Reaction mixtures (50 $\mu \mathrm{l})$ for nested PCR were as described for actin amplification except Expand Long Template System Taq DNA Polymerase (Roche Molecular Biochemicals) was used. Cycling parameters were $94^{\circ} \mathrm{C}$ for $2 \mathrm{~min}$ followed by 30 cycles of $94^{\circ} \mathrm{C}$ for $30 \mathrm{~s}$; $65^{\circ} \mathrm{C}$ for $30 \mathrm{~s}$; and $68^{\circ} \mathrm{C}$ for $5.5 \mathrm{~min}$. The process of amplifying out of the sequenced regions was repeated for genes PR-2 and PR-8. Primers AP1 and AP2 were paired with aj636 and aj637 for PR-2 amplification in the $5^{\prime}$ direction and with aj638 and aj639 for PR-8 amplification in the $3^{\prime}$ direction. PCR products were separated on $2 \%$ agarose gels, purified, and sequenced. An 18-bp region of apple PR-1 located between the amplicon from the aj263aj264 degenerate primer pair and the amplicon from the nested PCR was amplified with primers aj708 and aj629 and sequenced, making the PR-1 sequence continuous.

Isolation of RNA and cDNA synthesis. Twenty-four Jonathan apple seedlings grown in the greenhouse were sprayed to

Table 1. Sequences of specific and degenerate primers used for polymerase chain reaction (PCR) amplification of genes in apple genomic DNA and cDNA

\begin{tabular}{lcl}
\hline $\begin{array}{l}\text { Target gene } \\
\text { (protein family) }^{\text {a }}\end{array}$ & Primer ID & Primer sequence $^{\mathbf{b}}$ \\
\hline PR-1 & aj264 & GGNCAYTAYACNCARGTNGTNTGG \\
PR-1 & aj263 & TTNCCNGGNGGRTCRTARTTRCA \\
PR-1 & aj629 & ACCCTACACGAGCCGAGTTRCG \\
PR-1 & aj630 & CATGCCATGGCCAAACIACYTGIGTRTARTGIC \\
PR-1 & aj708 & GTAGGCGTTGGTCCCTGAC \\
PR-1 & aj709 & GATTGCAGTCGCCAACATGT \\
PR-2 & aj277 & TAYATHGCNGTNGGNAAYGA \\
PR-2 & aj278A & AACATNGCRAANAGRTANGT \\
PR-2 & aj636 & TCAGAGGGAGGGAAGGGATTGG \\
PR-2 & aj637 & AATTGCACTGTGGATGTTTTGGATGG \\
PR-2 & aj778 & TCCGATGCCATTGCTTTTG \\
PR-2 & aj779 & TTATGGACGAAACGGCAACA \\
PR-8 & aj281A & TAYTGGGGNCARAAYGGNAA \\
PR-8 & aj282A & TARAAYTGNACCCANACRTA \\
PR-8 & aj638 & CGGGTGGTGCGCAGTTCTAYGATGAG \\
PR-8 & aj639 & CTCAACGGACACAACGGACAGGCAAAAA \\
PR-8 & aj780 & CTCTTTTGAGCAGTTGGAACCA \\
PR-8 & aj781 & TGCCGGTAACCCCATGAA \\
Actin & aj665 & AAYTGGGAYGAYATGGARAA \\
Actin & aj666 & ATCCACATYTGYTGRAANGT \\
Actin & aj748 & AACTTCGTGTTGCTCCTGAAGAG \\
Actin & aj749 & CAGTAGTACGACCACTGGCATAGAG \\
$\ldots$ & AP1 & GGATCCTAATACGACTCACTATAGGGC \\
$\ldots$ & AP2 & AATAGGGCTCGAGCGGC \\
\hline
\end{tabular}

${ }^{a}$ Target gene family is putative based on most similar GenBank entry.

b Primers are listed $5^{\prime}$ to $3^{\prime}$. Degeneracy is indicated with the standard degenerate code, and "I" indicates an inosine nucleotide. runoff with a suspension of ASM at $1.5 \mathrm{~g}$ a.i./liter when the seedlings were 4 weeks old. Six of the youngest leaves from each of three replicates were harvested immediately before treatment on day 0 and at days 2,5 , and 7 postapplication, quick-frozen in liquid nitrogen, and stored at $-80^{\circ} \mathrm{C}$. Leaves harvested from seedlings sprayed with water were used as controls. The frozen leaves were ground in liquid nitrogen and then added to $3 \mathrm{ml}$ of preheated $\left(100^{\circ} \mathrm{C}\right)$ extraction buffer $(100 \mathrm{mM}$ Tris $\mathrm{HCl}$ [pH 8], $100 \mathrm{mM} \mathrm{LiCl}$, and $10 \mathrm{mM}$ EDTA, $1 \% \mathrm{wt} / \mathrm{vol}$ sodium dodecyl sulfate [SDS]) and $3 \mathrm{ml}$ Tris-saturated phenol. The mixture was vortexed for $1 \mathrm{~min}, 3 \mathrm{ml}$ of chloroform was added, and the solution was vortexed again. The mixture was centrifuged at $10,000 \mathrm{rpm}$ for $20 \mathrm{~min}$, the supernatant was collected, and the phenol/chloroform extraction was repeated. The supernatant from the second phenol/chloroform extraction was added to 1 volume of $4 \mathrm{M} \mathrm{LiCl}$ and precipitated at $4^{\circ} \mathrm{C}$ for 2 to $18 \mathrm{~h}$. The mixture was centrifuged as above, and the pellet was resuspended in $400 \mu \mathrm{l}$ of water. All water used for RNA extraction was deionized and autoclaved with $0.1 \%$ vol/vol diethyl pyrocarbonate. Total RNA was precipitated with 2.5 volumes of 200-proof ethanol and 0.1 volume of $3 \mathrm{M}$ sodium acetate, $\mathrm{pH} 5.2$, at $-20^{\circ} \mathrm{C}$ for 1 to $18 \mathrm{~h}$. RNA was pelleted by centrifugation at $11,950 \times g$ for $15 \mathrm{~min}$, resuspended in water, quantified, and stored at $-80^{\circ} \mathrm{C}$ in $5-\mu$ aliquots, each with $5 \mu \mathrm{g}$ of total RNA.

Each 5- $\mu$ l aliquot of total RNA was treated with RQ1 RNase-free DNase (Promega Corporation, Madison, WI) according to the manufacturer's protocol. RNA was precipitated with 2.5 volumes of absolute ethanol and 0.1 volume of $3 \mathrm{M}$ sodium acetate, $\mathrm{pH} 5.2$, at $-20^{\circ} \mathrm{C}$ for 1 to $18 \mathrm{~h}$. Samples were centrifuged at $11,950 \times$ $g$ for $15 \mathrm{~min}$, the supernatant was discarded, and the RNA pellet was allowed to dry. The RNA was then reverse-transcribed following the SuperScript II RNase $\mathrm{H}^{-}$ Reverse Transcriptase (Gibco BRL Life Technologies, Grand Island, NY) protocol for first strand cDNA synthesis using random primers. The reaction was diluted 1 to 10 and used for expression analysis.

Expression of PR genes using realtime PCR. Real-time PCR was performed using primer pairs aj708-aj709, aj778aj779, and aj780-aj781 for putative apple PR-1, PR-2, and PR-8 genes, respectively (Table 1). As a control, the actin gene was amplified under the same conditions using primers aj748-aj749. Parameters for primer design were 20 to $80 \%$ CG content, $\mathrm{T}_{\mathrm{m}}=$ 58 to $60^{\circ} \mathrm{C}$, and an amplicon length of 50 to $150 \mathrm{bp}$. The PR gene fragments were amplified with an ABI Prism 7700 sequence detection system (Applied Biosystems) that measures the fluorescence of the double-stranded DNA binding dye, SYBR Green. PCR mixtures (30- $\mu \mathrm{l}$ reactions) 
consisted of $1 \times$ SYBR PCR buffer, $3 \mathrm{mM}$ $\mathrm{MgCl}_{2}, 1 \mathrm{mM}$ dNTP Blend, $0.025 \mathrm{U} / \mu \mathrm{l}$

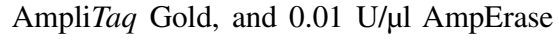
UNG from Applied Biosystems. To each mixture, $0.125 \mu \mathrm{g}$ of cDNA from each sample was added. Cycling conditions were $2 \mathrm{~min}$ at $50^{\circ} \mathrm{C}, 10 \mathrm{~min}$ at $95^{\circ} \mathrm{C}$, and 40 cycles of $15 \mathrm{~s}$ at $95^{\circ} \mathrm{C}$ and $1 \mathrm{~min}$ at $59^{\circ} \mathrm{C}$. Each run included a no-template control, a no-amplification control in which $0.07 \%$ (wt/vol) SDS was added to the reaction mixture, and a dilution series of target template. As a relative constitutive control, actin was amplified from each sample within a run. For each set of primers, individual sample amplifications (PR and actin) were replicated three times and controls were replicated twice. The concentration of target sequence in each sample was determined from the dilution series of target template for both PR and actin. The expression of PR-proteins is reported as a concentration ratio of PR to actin.

ASM efficacy for fire blight control. The experiment was conducted in 1999 and 2000 on 28-year-old Jonathan apple trees located at the Plant Pathology Research Farm in East Lansing. The experimental area was a single row of trees located on the northern edge of the orchard. Each treatment was replicated three times in 1999 and four times in 2000. The experimental design was a randomized complete block with single-tree plots. Two ASM (Actigard 50WG, Syngenta) treatments at $75 \mathrm{mg}$ a.i./liter were initiated 1 week prebloom, and successive sprays were applied on 7- or 14-day intervals. Streptomycin (Agrimycin 17, Syngenta) at $100 \mathrm{mg}$ a.i./liter was applied twice during bloom and then on a 7-day interval. All applications were applied to runoff.

Storms occurred at the end of petal fall in both 1999 and 2000, resulting in infection events both years. The simultaneous occurrence of symptoms on blossoms and shoots on the same spur often made it impossible to distinguish blossom blight from shoot blight; therefore, disease incidence associated with these storms was recorded as strikes per tree. During bloom, 50 spurs per tree were labeled and the stigmatic surfaces of two blossoms per spur inoculated with $E$. amylovora strain Ea110. All labeled spurs were excluded when the data were recorded.

After either three 7-day or two 14-day ASM sprays, 25 shoots per tree were inoculated by bisecting two terminal leaves with scissors dipped in E. amylovora strain Ea110 at $1 \times 10^{7} \mathrm{CFU} / \mathrm{ml}$ (21). The inoculum was prepared by suspending in sterile water bacteria from 18-h-old cultures in Luria-Bertani (LB) broth (23). Inoculations were performed randomly by block. Percentages of inoculated shoots infected and canker extension (length of lesion/length of shoot) in blighted shoots were evaluated 2 weeks later.

In July 2000, two experiments at separate locations were conducted on 3-year- old Fuji apple trees in a high-density planting to assess the efficacy of increasing rates of ASM $(37.5,75,150$, and $300 \mathrm{mg}$ a.i./liter) for limiting the development of fire blight in shoots. For comparison, streptomycin was applied at $100 \mathrm{mg}$ a.i./liter separately and in combination with ASM at $75 \mathrm{mg}$ a.i./liter. Each treatment was sprayed on 7-day or 14-day intervals. The experimental designs were randomized complete blocks with each treatment replicated three times on single-tree plots. Ten shoots per tree were inoculated 1 week after the first application with scissors dipped in E. amylovora strain Ea110 at $1 \times$ $10^{9} \mathrm{CFU} / \mathrm{ml}$ as previously described. Percentage of canker extension within blighted shoots was evaluated; following a comparison of the experiments with an analysis of variance (ANOVA) which found no significant difference $(P=0.6)$, the data from the two experiments were combined for analysis.

ASM in vitro assay. Seeded lawns of $E$. amylovora strain Ea110 were prepared by combining $2.5 \mathrm{ml}$ of LB soft agar and 250 $\mu \mathrm{l}$ of Ea110, grown to an optical density of 0.5 at $600 \mathrm{~nm}$ in $3 \mathrm{ml}$ of LB broth at $27^{\circ} \mathrm{C}$. The soft agar was poured over the surface of LB plates. ASM, $300 \mu \mathrm{g}$; streptomycin, $60 \mu \mathrm{g}$; and sterile water were applied to three 1-cm-diameter filter paper disks (Schleicher and Schuell, Inc., Keene, NH). The impregnated disks were placed on seeded lawns, and the plates were incubated at $27^{\circ} \mathrm{C}$ for 2 days. The diameter of inhibition was recorded for each plate.

Statistical analyses. Data analyses were performed with SAS software (SAS Institute, Cary, NC). PR protein expression within days in treated and untreated seedlings was compared with a one-tailed $t$ test. Significant differences between treatments in disease severity and incidence in the trial on Jonathan were determined with a least significant difference (LSD) pair-wise comparison and in the trial on Fuji by Tukey's honestly significant difference (HSD) pair-wise comparison. The effects of increasing rates of ASM on disease severity were evaluated using contrasts testing for linear, quadratic, and cubic trends.

\section{RESULTS}

PR-protein genes identified in apple. A PCR product was amplified from both apple DNA and cDNA with each pair of degenerate primers. Aj264-aj263 gave a product of approximately $125 \mathrm{bp}$; aj277aj278A and aj281A-aj282A each gave a product of approximately $550 \mathrm{bp}$; and aj665-aj666 gave a product of $850 \mathrm{bp}$ (Fig. 1). Sequencing of each PCR fragment confirmed the presence of nucleotide sequences in the PR-1, PR-2, PR-8, and actin gene families. The sequence data from the initial PCR fragments and the ScaI library were combined, and their deduced amino acid sequences were compared with those of various PR proteins deposited in GenBank. Putative apple PR-1 amino acid sequence (103 amino acids) had 98\% identity with a PR-1b protein from Pyrus pyrifolia cultivar Wangkeumbae (AAF78528); putative apple PR-2 sequence (273 amino acids) had $58 \%$ identity ( $72 \%$ similarity) to an endo-1,3- $\beta$-D-glucosidase (PR-2 family) from Cicer arietinum (CAA10167.1); putative apple PR-8 sequence (260 amino acids) exhibited $93 \%$ identity to an endochitinase class III protein (PR-8 family) from P. pyrifolia (BAA96445.1); and putative apple actin sequence (259 amino acids) exhibited $97 \%$ identity to the actin protein in Gossypium hirsutum (T51175).

Effect of ASM on PR-protein gene expression. Beginning 2 to 5 days after treatment, cDNA derived from total RNA extracted from apple leaves of seedlings

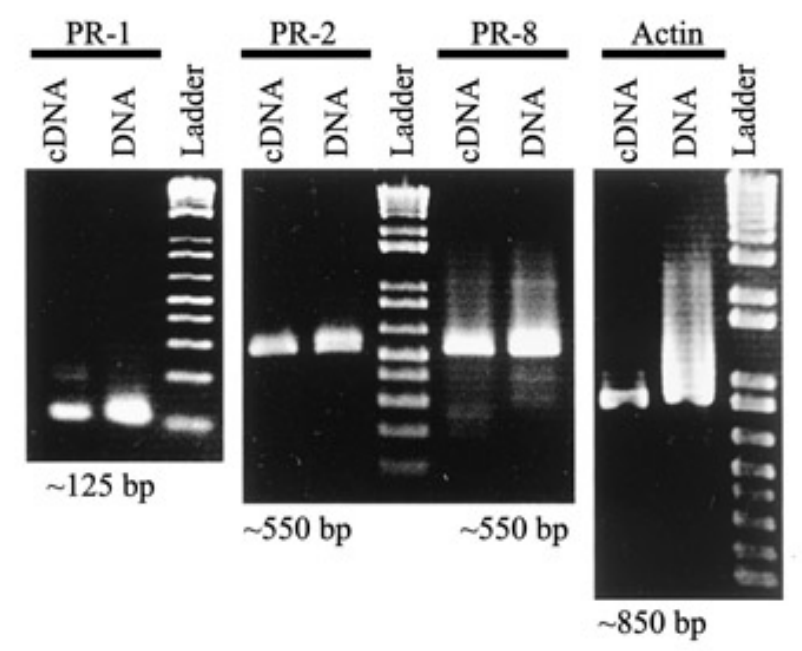

Fig. 1. Detection by agarose gel electrophoresis of pathogenesis-related (PR) and actin genes amplified from Gala apple DNA and Jonathan apple cDNA with degenerate primer pairs aj264-aj263 (PR1), aj277-aj278A (PR-2), aj281A-aj282A (PR-8), and aj665-aj666 (actin). Ladder lanes are 1-kb Ladder Plus (Life Technologies). 
treated with ASM at $1.5 \mathrm{~g}$ a.i./liter exhibited 10- to 100-fold greater expression of PR-genes than cDNA derived from leaves of water-treated seedlings (Fig. 2). Expression of PR-1 and PR-2 in AMS-treated seedlings was significantly higher $(P<$ $0.05)$ than in water-treated seedlings 2 to 7 days after treatment (Fig. 2A and B), and the expression of PR-8 was significantly higher $(P<0.05) 5$ to 7 days after treatment (Fig. 2C).

Effect of ASM on fire blight. ASM significantly reduced the incidence of natural infections of fire blight associated with storms that occurred shortly after petal fall in 1999 and again in 2000 (Fig. 3A). In both years, trees sprayed with ASM on a 7day schedule exhibited fewer fire blight strikes than trees sprayed on a 14-day schedule (Fig. 3A). Streptomycin was numerically the most effective treatment each year, providing over $95 \%$ control of these infections (Fig. 3A).

ASM applied at weekly intervals three times before inoculation and three times after inoculation significantly reduced the percentage of inoculated shoots with fire blight infections in 1999, but not in 2000

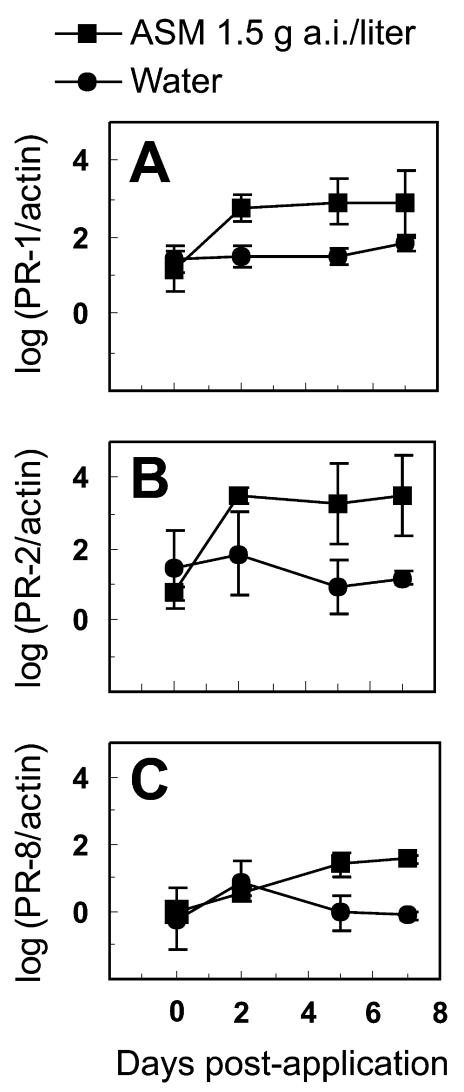

Fig. 2. Expression of A, PR-1, B, PR-2, and C, PR-8 in cDNA prepared from total RNA extracts from apple leaf samples collected 0, 2, 5, and 7 days after Jonathan seedlings were sprayed with acibenzolar- $S$-methyl (ASM) or water. Concentrations of cDNA for each gene were measured with real-time polymerase chain reaction (PCR) using actin as a quantity standard. Error bars denote the standard deviation for each mean. Asterisk (*) indicates that the error bars for these means do not overlap.
(Fig. 3B). In both years, the extension of fire blight in infected shoots treated weekly with ASM was less than that observed in the control (Fig. 3C). However, ASM applied on a 14-day schedule did not reduce fire blight in the inoculated shoots compared with the control (Fig. 3B and C). Streptomycin applied twice in bloom and weekly thereafter reduced the percentage of shoots with fire blight in both years, but only reduced lesion expansion in 1999.

Two experiments that evaluated increasing rates of ASM on the extension of fire blight lesions in inoculated shoots of Fuji apple were compared with an ANOVA. No significant differences were detected $(P=$ $0.6)$; therefore, the data from the two experiments were pooled for analysis. Extension of the cankers was reduced as the rate
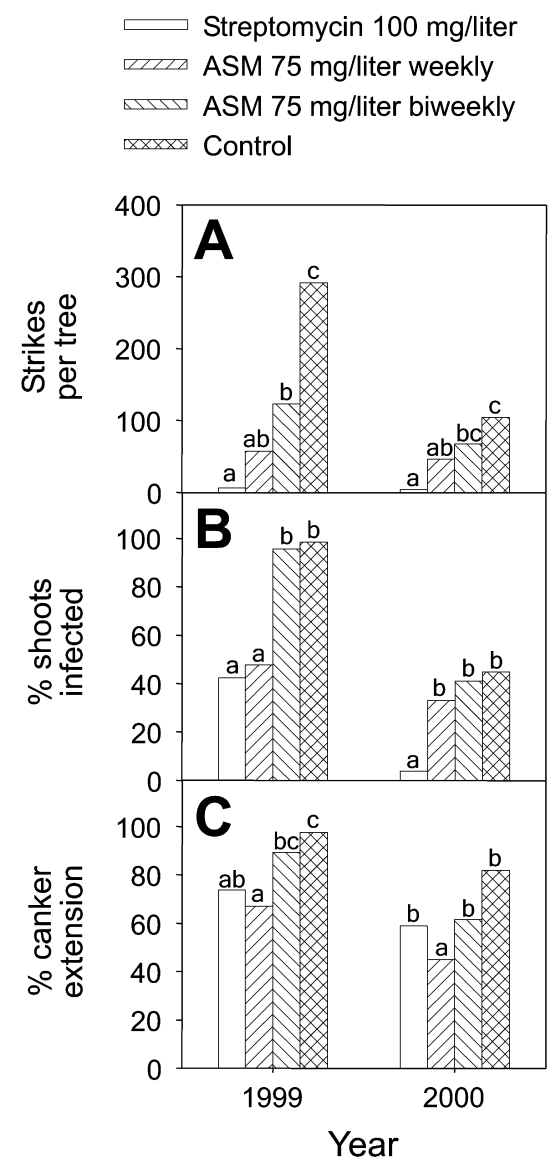

Fig. 3. A, Fire blight strikes per tree and the B, incidence and $\mathbf{C}$, severity of fire blight on Jonathan apple inoculated with Erwinia amylovora. Numbers of strikes were evaluated 16 and 12 days after a severe storm in 1999 and 2000 , respectively. Percent shoot infection is the average percentage of inoculated shoots that became infected. Of the infected shoots, severity of infection was measured in the current year's growth as length of canker divided by length of shoot. Percent shoots infected and percent canker extension were evaluated 2 weeks after inoculations were made. Bars within a year labeled with the same letter are not significantly different $(P>0.05)$. LSDs were determined within years according to ANOVA. of ASM applied weekly was increased from 0 to $300 \mathrm{mg}$ a.i./liter (Fig. 4). A combination of ASM at $75 \mathrm{mg}$ a.i./liter with streptomycin at $100 \mathrm{mg}$ a.i./liter was also tested. This combination significantly limited canker development compared with the control $(68.8 \%$ of the total shoot infected for the combination versus $94.6 \%$ of the total shoot infected for the control). The combination was more effective in limiting canker development than ASM at $75 \mathrm{mg}$ a.i./liter (canker length of $87.9 \%$ ) and streptomycin at $100 \mathrm{mg}$ a.i./liter (canker length of $87.6 \%$ ). When the treatments were applied on a 14-day schedule, there was no significant difference observed between any of the treatments and the control $(P>0.05$; data not shown).

Effect of ASM on E. amylovora in vitro. No inhibition of growth of E. amylovora strain Ea110 was observed near the margin of ASM-treated assay disks, but growth of Ea110 was inhibited when assay disks were treated with streptomycin (data not shown).

\section{DISCUSSION}

New strategies are desperately needed for the control of fire blight on apple and other pome fruits. Fundamental changes that have occurred over the last two decades in the way apples are grown have substantially increased the risk of severe losses from fire blight in orchards worldwide. Today, apple plantings are made up of susceptible cultivars propagated on susceptible rootstocks planted at high density per hectare (16). These changes in horticultural practices have coincided with the development of streptomycin-resistant strains of E. amylovora in several areas worldwide (12). Due to the current debate concerning the use of antibiotics in agriculture, no new bactericides have been developed for the control of fire blight on apples since streptomycin was introduced in 1955.

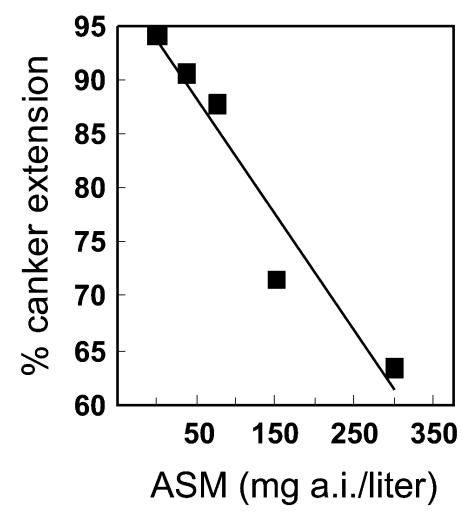

Fig. 4. Relationship of rate of acibenzolar-Smethyl (ASM) to extension of fire blight in 1year-old shoots of Fuji apple trees inoculated with Erwinia amylovora in 2000. Treatments were applied weekly for 3 weeks, and inoculations were made 7 days after the first application. Line depicts a linear trend $(y=-0.11 x+$ $\left.94 ; R^{2}=0.93\right)$. 
Rootstocks with resistance to fire blight have recently been developed; their adoption by the apple industry is just starting and should increase as more apple trees propagated on these stocks become available. High quality apple cultivars with fire blight resistance look promising (20); however, the public is concerned about potential human and environmental hazards of transgenic crops. The technique of inducing resistance in apple trees to fire blight is exciting, but its potential as a viable control strategy remains to be established.

We have demonstrated that treating apple with foliar applications of ASM can provide a significant level of fire blight control. The insensitivity of E. amylovora to high rates of ASM in an agar-plate assay suggests that, unlike streptomycin, which has a direct effect on bacteria, ASM has an indirect effect on the bacteria by inducing resistance in apple to the pathogen. There was a significant reduction in the incidence of natural infection at petal fall on Jonathan trees when weekly foliar applications of ASM were initiated 1 week before blooms opened (Fig. 3A). Bacteria had been applied to stigmatic surfaces of two blossoms on each of 50 spurs per tree prior to each storm in 1999 and 2000; new blossom and shoot infections were observed 7 to 10 days later. Ingress likely occurred through wounds caused by premature removal of flower petals exposing the scars and the tearing of leaves observed after each storm. Introduced inoculum was likely the source of the infections since rifampicin-resistant E. amylovora similar to strain Ea110 was isolated from spurs that had not been inoculated artificially. There was also a significant reduction in shoot blight with weekly application of ASM three times before and three times after inoculation (Fig. 3B and C, Fig. 4).

ASM has recently been developed and registered to prevent bacterial spot and speck infections on tomato, downy mildew on spinach, and blue mold on tobacco in the United States, where it is used at low rates (18). Based on experience with herbaceous plants, the manufacturer proposed testing a rate range beginning at $37.5 \mathrm{mg}$ a.i./liter, but we decided to use $75 \mathrm{mg}$ a.i./liter in the majority of our field tests based on a study by Brisset et al. (2) demonstrating that higher rates might be necessary. Although weekly spray programs using this rate of ASM provided a reduction in the incidence of fire blight, higher rates (150 and $300 \mathrm{mg}$ a.i./liter) were more effective in preventing shoot blight. Our results are consistent with the recent report by Brisset et al. (2); they reported about $50 \%$ control of blossom blight on Golden Delicious trees treated twice before inoculation and twice after with ASM at $100 \mathrm{mg}$ a.i./liter. On some herbaceous plants, the effectiveness of ASM is often described as long-lasting: at least 2 weeks on pepper (22) and full season on wheat (9). In all experiments, ASM applied on a 14-day schedule was less effective in reducing the length of fire blight lesions than on a 7-day schedule. Increasing the rate of ASM in 14-day schedules did not provide control similar to 7-day schedules. Based on these experiments, the spray interval for ASM should be about 7 days; unfortunately, multiple applications of ASM at 7-day intervals may not be economically feasible.

To allow sufficient time for the induction of resistance, all experiments on Jonathan apple with ASM were initiated when the trees were at pink or about 1 week before bloom, while treatments with streptomycin were delayed until bloom. Control on trees sprayed with ASM and streptomycin was superior to ASM alone; combining schedules of ASM and streptomycin appears to offer additional disease control compared with ASM alone. Although it is possible to tank-mix ASM and streptomycin, the different timing scenarios required for the two compounds may make tank mixing impractical.

ASM is known to be an inducer of SAR in tobacco, wheat, and Arabidopsis $(8,9,15)$; consequently, it is not surprising that ASM effects a similar result in apple. The resistance to E. amylovora induced in apple by ASM is likely due to the activation of defense responses, which is typically characterized by PR proteins $(19,30)$. Our choice of target PR genes was based on their occurrence in a wide range of plant species, their generally high level of expression, and their modes of action. PR1 induces anti-oomycete activity in vitro, but it was chosen primarily because it is highly expressed in most plants, reaching 10,000 -fold induction in tobacco (1). PR-8 shows class III chitinase activity in vitro and was chosen for our study because it is the most abundant chitinase in infected cucumber, and because of its structural homology with a lysozyme that may adversely affect a bacterial pathogen (19). PR-2 is a $\beta$-1,3-glucanase and was chosen because PR-2 protein induction was previously correlated with resistance to fire blight in apple seedlings treated with ASM (2).

Initially we identified fragments of three genes in apple that are associated with SAR in herbaceous plants: PR-1, PR-2, and PR-8. When we analyzed the expression of RNA transcripts in apple seedlings following ASM treatment, we found elevated expression of each PR gene. Expression of these genes was elevated 2 to 7 days after ASM treatment; PR-1 and PR-8 expression was increased after 2 days and remained high 5 and 7 days after treatment, while PR-2 expression was increased after 5 days and remained high on day 7. However, it was necessary to use high rates of ASM (1.5 g a.i./liter) because the results obtained using lower rates were highly variable between each replication. The detection of increased levels of PR proteins
2 to 7 days after ASM treatment is consistent with our observation in the field that fire blight control improved with weekly application intervals compared with 14-day intervals.

Using an enzyme assay, Brisset et al. (2) were able to show that increased expression of PR-2 was sustained for 17 days in ASM-treated apple seedlings. Although PR-protein induction in apple seedlings correlates with disease resistance induction in trees, it is possible that the duration of PR-protein induction may not correlate with the maintenance of disease resistance, or that PR-protein expression may not correlate with this specific form of induced resistance. Reports by Fraser (6), Fraser and Clay (7), and Van Loon (29) suggest that PR-protein induction may not correlate with disease resistance in all plants or under certain inducing conditions. In our field studies, it appeared that the increase in resistance associated with the expression of these genes declines within 14 days since biweekly schedules of ASM were not as effective as weekly schedules in controlling fire blight.

The expression of PR genes has been correlated with the induction of SAR in many plants, but this is one of the first studies where molecular assays were used to study the response in fruit crops. Therefore, sequence and expression analysis of the PR genes should allow a fuller understanding of the response of fruit and other crop plants to applications of ASM. Also, the PCR assays developed in this study should be useful to similar studies on other fruit crops. The PR-1 and PR-8 genes in Pyrus pyrifolia and Malus $\times$ domestica in particular exhibit a high degree of identity, suggesting that these assays should be useful for studying the effects of plant defense elicitors on other members of the Rosaceae. The similarity of PR-1 and PR-8 between $P$. pyrifolia and Malus $\times$ domestica also suggests that these species may share similar responses to SAR inducers.

ASM should be considered as a supplement rather than as a replacement for the bactericides currently used to control fire blight. Although ASM reduced the incidence and severity of fire blight in two seasons favorable for infection, the amount of disease that remained could increase during the summer to high levels. ASM applied weekly and streptomycin applied at critical times during bloom should be more effective for the management of fire blight than either approach alone. In addition, ASM should reduce the need for streptomycin in the postbloom period, thereby decreasing the risk of development of streptomycin-resistant strains.

\section{ACKNOWLEDGMENTS}

This research was supported in part by Syngenta Crop Protection, the Michigan Agricultural Experiment Station, the Michigan Apple Research Committee, and USDA/CSREES Agreement 00- 
34367-8993. We thank Elise Schnabel and Gayle McGhee for technical advice, and Gail Ehret, Katalin Kása, and Dave Almy for technical assistance.

\section{LITERATURE CITED}

1. Alexander, D., Goodman, R. M., Gut-Rella, M., Glascock, C., Weymann, K., Friedrich, L., Maddox, D., Ahl-Goy, P., Luntz, T., Ward, E., and Ryals, J. 1993. Increased tolerance to two oomycete pathogens in transgenic tobacco expressing pathogenesis-related protein 1a. Proc. Natl. Acad. Sci. U.S.A. 90:7327-7331.

2. Brisset, M.-N., Cesbron, S., Thomson, S. V., and Paulin, J.-P. 2000. Acibenzolar-S-methyl induces the accumulation of defense-related enzymes in apple and protects from fire blight. Eur. J. Plant Pathol. 106:529-536.

3. Chiou, C.-S., and Jones, A. L. 1991. The analysis of plasmid-mediated streptomycin resistance in Erwinia amylovora. Phytopathology 81:710-714.

4. Coyier, D. L., and Covey, R. P. 1975. Tolerance of Erwinia amylovora to streptomycin sulfate in Oregon and Washington. Plant Dis. Rep. 59:849-852.

5. Csinos, A. S., Pappu, H. R., McPherson, R. M., and Stephenson, M. G. 2001. Management of Tomato spotted wilt virus in fluecured tobacco with acibenzolar-S-methyl and imidacloprid. Plant Dis. 85:292-296.

6. Fraser, R. S. S. 1982. Are "pathogenesisrelated' proteins involved in acquired systemic resistance of tobacco plants to tobacco mosaic virus? J. Gen. Virol. 58:305-313.

7. Fraser, R. S. S., and Clay, C. M. 1983. Pathogenesis-related proteins and acquired systemic resistance: Causal relationship or separate effects? Neth. J. Plant. Pathol. 89:283292.

8. Friedrich, L., Lawton, K., Ruess, W., Masner, P., Specker, N., Gut Rella, M., Meier, B., Dincher, S., Staub, T., Uknes, S., Metraux, J., Kessman, H., and Ryals, J. 1996. A benzothiadiazole derivative induces systemic acquired resistance in tobacco. Plant J. 10:6170.

9. Gorlach, J., Volrath, S., Knauf-Beiter, G., Hengy, G., Beckhove, U., Kogel, K.-H., Oostendorp, M., Staub, T., Ward, E., Kessmann, H., and Ryals, J. 1996.
Benzothiadiazole, a novel class of inducers of systemic acquired resistance, activates gene expression and disease resistance in wheat. Plant Cell 8:629-643.

10. Huang, Y., Deverall, B. J., Tang, W. H., Wang, W., and Wu, F. W. 2000. Foliar application of acibenzolar-S-methyl and protection of postharvest rock melons and Hami melons from disease. Eur. J. Plant Pathol. 106:651-656.

11. Ishii, H., Tomita, Y., Horio, T., Narusaka, Y., Nakazawa, Y., Nishimura, K., and Iwamoto, S. 1999. Induced resistance of acibenzolar-Smethyl (CGA 245704) to cucumber and Japanese pear diseases. Eur. J. Plant Pathol. 105:77-85.

12. Jones, A. L., and Schnabel, E. L. 2000. The development of streptomycin-resistant strains of Erwinia amylovora. Pages 235-251 in: Fire Blight: The Disease and Its Causative Agent, Erwinia amylovora. J. L. Vanneste, ed. CABI Publishing, New York.

13. Kessmann, H., Staub, T., Ligon, J., Oostendorp, M., and Ryals, J. 1994. Activation of systemic acquired disease resistance in plants. Eur. J. Plant Pathol. 100:359-369.

14. Kunz, W., Schurter, R., and Maetzke, T. 1997. The chemistry of benzothiadiazole plant activators. Pestic. Sci. 50:275-282.

15. Lawton, K. A., Friedrich, L., Hunt, M., Weymann, K., Delaney, T., Kessmann, H., Staub, T., and Ryals, J. 1996. Benzothiadiazole induces disease resistance in Arabidopsis by activation of the systemic acquired resistance signal transduction pathway. Plant J. 10:71-82.

16. Longstroth, M. 2001. The 2000 fire blight epidemic in southwest Michigan apple orchards. Compact Fruit Tree 34:16-19.

17. Louws, F. J., Wilson, M., Campbell, H. L., Cuppels, D. A., Jones, J. B., Shoemaker, P. B., Sahin, F., and Miller, S. A. 2001. Field control of bacterial spot and bacterial speck of tomato using a plant activator. Plant Dis. 85:481-488.

18. Moffat, A. S. 2001. Finding new ways to fight plant diseases. Science 292:2270-2273.

19. Neuhaus, J. M. 1999. Plant chitinases (PR-3, PR-4, PR-8, PR-11). Pages 77-105 in: Pathogenesis-Related Proteins in Plants. S. K. Datta and S. Muthukrishnan, eds. CRC Press, New York.

20. Norelli, J. L., and Aldwinckle, H. S. 2000. Transgenic varieties and rootstocks resistant to fire blight. Pages 275-292 in: Fire Blight: The Disease and Its Causative Agent, Erwinia amylovora. J. L. Vanneste, ed. CABI Publishing, New York.

21. Ritchie, D. F., and Klos, E. J. 1977. Isolation of Erwinia amylovora bacteriophage from aerial parts of apple trees. Phytopathology 67:101-104.

22. Romero, A. M., Kousik, C. S., and Ritchie, D. F. 2001. Resistance to bacterial spot in bell pepper induced by acibenzolar-S-methyl Plant Dis. 85:189-194.

23. Sambrook, J., Fritsch, E. F., and Maniatis, T. 1989. Appendix A: Bacterial media, antibiotics, and bacterial strains, Page A.1 in: Molecular Cloning a Laboratory Manual, 2nd ed vol. 3. Cold Spring Harbor Laboratory, Cold Spring Harbor, NY.

24. Schroth, M. N., Thomson, S. V., and Moller, W. J. 1979. Streptomycin resistance in $E r-$ winia amylovora. Phytopathology 69:565-568.

25. Shaffer, W. H., and Goodman, R. N. 1985 Appearance of streptomycin resistant Erwinia amylovora in Missouri apple orchards. (Abstr.) Phytopathology 75:1281.

26. Siebert, P. D., Chenchik, A., Kellogg, D. E. Lukyanov, K. A., and Lukyanov, S. A. 1995. An improved PCR method for walking in un cloned genomic DNA. Nucleic Acids Res 23:1087-1088.

27. Steiner, P. 2000. Integrated orchard and nursery management for the control of fire blight. Pages 339-358 in: Fire Blight: The Disease and Its Causative Agent, Erwinia amylovora. J. L. Vanneste, ed. CABI Publishing, New York.

28. Sticher, L., Mauch-Mani, B., and Metraux, J P. 1997. Systemic acquired resistance. Annu. Rev. Phytopathol. 35:235-270.

29. Van Loon, L. C. 1997. Induced resistance in plants and the role of pathogenesis-related proteins. Eur. J. Plant. Pathol. 103:753-765.

30. Ward, E. R., Uknes, S. J., Williams, S. C., Dincher, S. S., Wiederhold, D. L., Alexander, D. C., Ahl-Goy, P., Metraux, J.-P., and Ryals, J. A. 1991. Coordinate gene activity in response to agents that induce systemic acquired resistance. Plant Cell 3:1085-1094.

31. White, R. F. 1979. Acetylsalicylic acid (aspirin) induces resistance to Tobacco mosaic virus in tobacco. Virology 99:410-412. 